\title{
The Impact Of National Environment Of A Company On Its Financial Policy
}

\author{
Katarína Belanová \\ University of Economics in Bratislava, Faculty of National Economy, Department of Finance
}

\begin{abstract}
Current business world is a subject of constant changes, which are caused by the growing instability of business environment, both in national and global scale. The paper deals with one of these two parts, namely with the national environment. It consists of factors and conditions that arise independently from the will of the company. The company can not influence the conditions; it can only adjust to them that means to use potential opportunities or avoid threats. The aim of the paper is to present those parts of the social surroundings, which have the most significant influence on the financial decisions of a company. Regarding this, we analyze the development of the basic macroeconomic indicators of the Slovak Republic.
\end{abstract}

Keywords: National Environment, Corporate Financial Policy, Doing Business, Index of Economic Freedom

\section{Introduction}

Every company is an organic part of the economy of the country. It exists, develops or declines in interaction with economic entities, bodies, and organizations that surround it and influence its decision-making. The success of financial decision-making and corporate fiscal policy as a whole lies in careful monitoring of the state and development of the business environment, its permanent evaluation and drawing of the conclusions from the findings learned. Ludvík (2005) says that business climate is an integral part of the environment, as well as entrepreneurship, is an integral part of life. It is very diverse and structured. It has its factual, time, spatial, efficiency and effectiveness dimension.

Similar to that, Needle (2004) defines the business environment as a part of the environment, which consists of all factors that exist outside the enterprise and interact. All firms are, to a certain extent, limited by the environment, in which they work. On the other hand, they influence the environment with their activity. These mutual interactions between the environment and the firm can be seen in three levels (see Figure 1):

- Local level - the firm cooperates with local authorities of a certain environment (e.g. when the company plans to expand its buildings, it will need the agreement of the municipal councils) and its marketing and personal strategy is substantially influenced by firms operating in the same market.

- National level - the firm is influenced mostly by factors of the national environment, like interest rate, inflation, the national policy of employment.

- International level - the firm is affected by the international policy of international prices, regulations of supranational bodies like WTO and EU. 


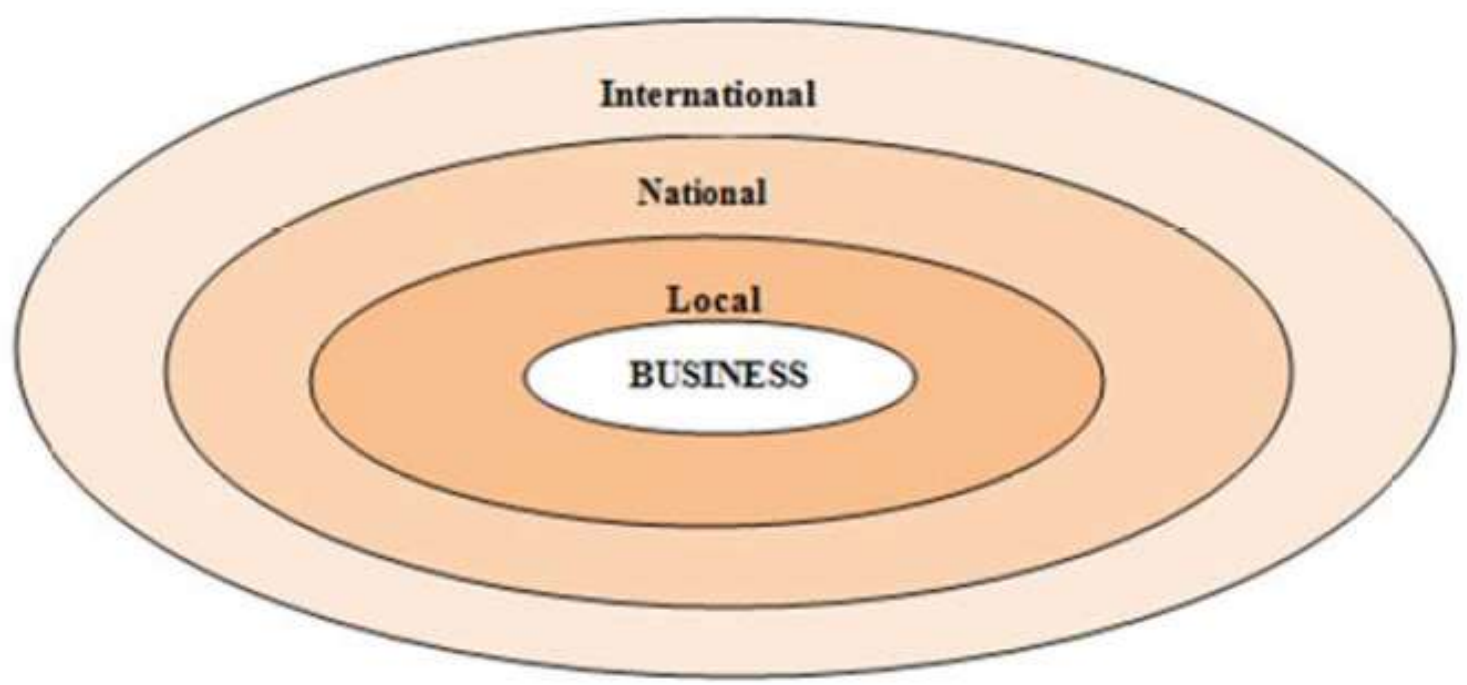

Figure 1: Levels of business environment

Source: Needle, 2004

An ability of the company to influence the environment decreases when it moves from the local towards the international context. At the same time, the ability of the company to influence the environment grows with its size. The issue solved is undoubtedly important for the makers of the state economic policy, because the creation of an appropriate business environment is a major factor in business sector development, esp. for SMEs as their main part. To improve the business climate for SMEs' development, it is necessary to monitor the aspects of the national environment which influence their financial policy.

We use the classification of the business environment into three levels in this paper. We dedicate our attention to the middle level, i.e. the national level. According to Král'ovič and Vlachynský (2011), the national environment is influenced by the development of the world economy, as well as by the effect of the economic policy in the state. The aim of the paper is to present those parts of the social surroundings, which have the most significant influence on the financial decisions of a company. We refer to the extent to which the crisis had hit the Slovak economy and when it was fully apparent through analysis of the core macroeconomic indicators of the Slovak Republic.

\section{Parts of the National Corporate Environment}

We take the following aspects as parts of the national environment mostly influencing the financial policy of a company:

- Economic development,

- Influence of the public finance,

- State of the currency and monetary policy,

- Inflation rate,

- Development of the financial policy,

- The other parts of the regulatory environment.

As we mentioned before, companies can influence these external factors by their behavior only in a limited way; they have to accept them as given ones, and they have to adjust their performance according to them.

\subsection{Economic development}

The company has to be able to extract the relevant information from the data on economic development: what volume of demand for products of the company as a whole and the portfolio can be expected in the future and what development of the input and output prices will be. These are the relevant input data, which are subsequently followed by the process of financial planning, they are subject to the decision on the need to obtain additional financial resources, the forms of their acquisition, the allocation of funds to individual assets and even. Current state and development of boom can be summarized by the indicators of the boom can be summed up by the indicators of 


\section{Katarína Belanová}

The Impact Of National Environment Of A Company On Its Financial Policy

production and employment. Table 1 shows, how the observed indicators developed in the SR from the beginning of the 21 st century.

Table 1: Development of the GDP and unemployment in the SR

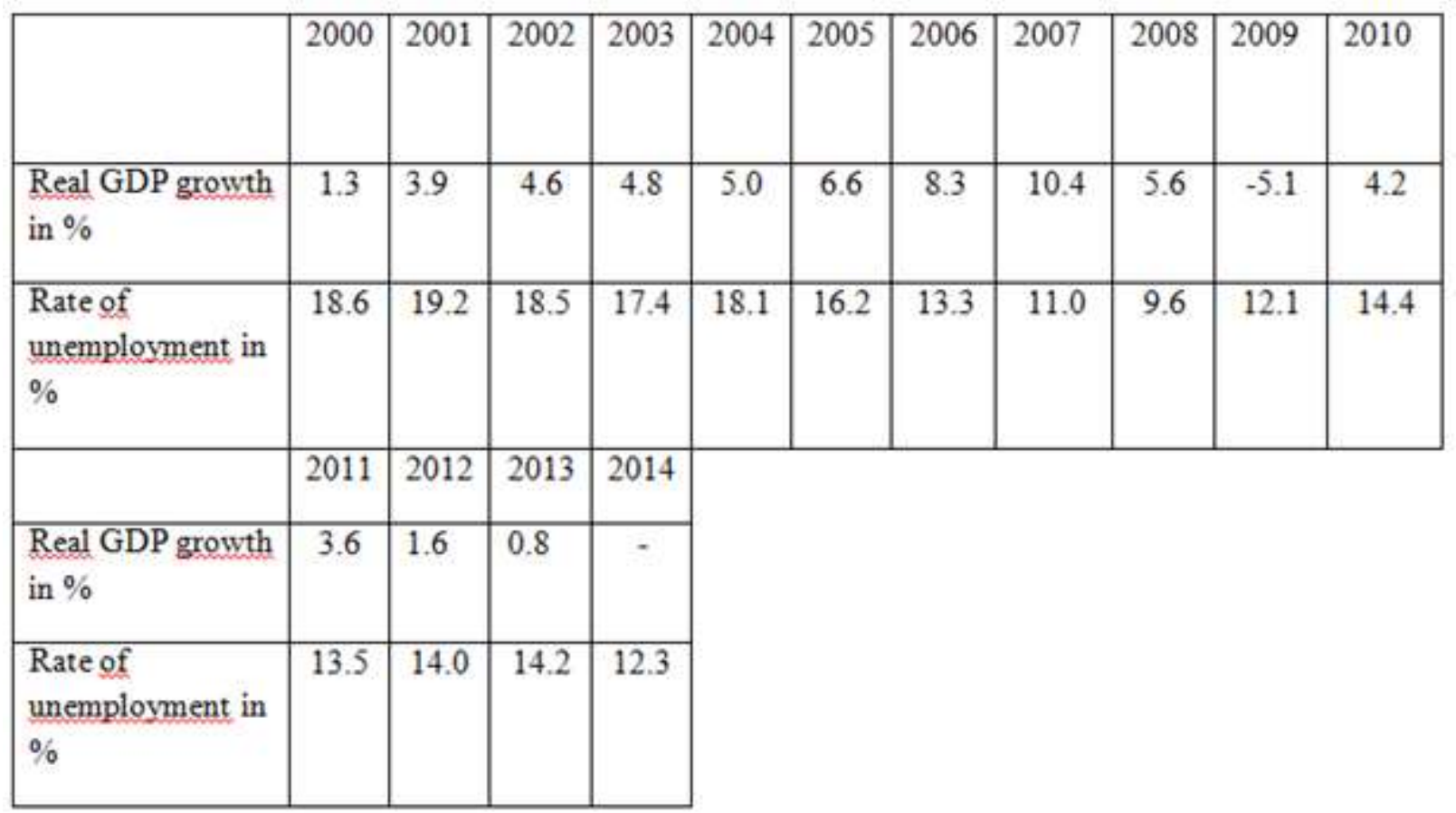

Source: Own elaboration from Eurostat data

In the years before the onset of the financial and economic crisis Slovakia reached accelerating the pace of growth, in 2007 it was even the highest GDP growth of all EU countries. The data reveal how deep the crisis hit. The intensity of the decline in 2009 is caused mainly by the great openness of the economy, i.e., its dependence on foreign trade. The high level of unemployment is one of the most serious problems of the Slovak economy. After a gradual decline since 2004, the crisis caused a turning point here. Its decline will be restored after an extended period (Škrovánková, L., and Škrovánková, P., 2012).

\subsection{Impact of public finance}

Public finance sector includes the issue of the state budget, local budget and public funds (Válek and Neupauerová, 2009). Regarding the state budget, issues of taxes, subsidies, customs and the overall condition of the state budget - its surpluses or deficits are necessary for the entrepreneurial sphere (Rabatinová and Kušnírová, 2013). Table 2 shows an overview of the overall condition of the state budget as a percentage of GDP.

Table 2: State of the state budget (\% of GDP)

\begin{tabular}{|l|l|l|l|l|l|l|l|l|l|l|}
\hline & 2000 & 2001 & 2002 & 2003 & 2004 & 2005 & 2006 & 2007 & 2008 & 2009 \\
\hline balance & -12.3 & -6.5 & -8.2 & -2.7 & -2.3 & -2.8 & -3.5 & -1.9 & -2.2 & -6.8 \\
\hline
\end{tabular}

\begin{tabular}{|l|l|l|l|}
\hline 2010 & 2011 & 2012 & 2013 \\
\hline-7.54 & -4.76 & -4.48 & -2.77 \\
\hline
\end{tabular}

Source: SO SR - Slovstat 


\subsection{Impact of the state of currency and monetary policy}

State of currency and monetary policy are closely connected with fiscal policy. Economic policy and its influence on the business sphere is more effective, as the closer coordination between the fiscal and monetary policy in a state is.

\subsection{Impact of inflation}

Enterprises have experience especially with a more or less intense negative effect of inflation. The experience of some countries (especially Japan and some other countries like for example Hong Kong, Lithuania and others in recent years, but according to the result of 2014 also the SR) showed that also the deflationary trend - i.e., lowering prices - has in the economy as a whole and also in the business sphere adverse consequences (Gertler and Sivák, 2013).

Regarding Slovakia, Table 3 shows that the growth rate of consumer price levels has had a downward trend in the longterm (from 2000) with fluctuations in single years.

\subsection{The other parts of the regulatory environment for doing business}

We have in mind particularly the various forms of burden which is borne by businesses as a result of administrative and other acts related to business.

Companies are exposed to various obligations enshrined in legislation or regulations in general. The role of regulations is usually to ensure the fulfillment of certain social objectives. It is clear that regulatory measure protecting consumers, shareholders and public companies without overloading of the companies helps to create an environment in which the private sector can prosper. A reduction in unnecessary administrative burdens in today's economic conditions when businesses have fewer resources and need to invest to remain competitive is more important than ever (Jančovičová Bognárová, 2012).

In this context, there are various international rankings for evaluation of the business environment. They are an excellent reference for investments. There are dozens of them, and they are developed by very different actors (from international institutions to credit rating agencies). We present the surveys realized by the World Bank and the Heritage Foundation (i.e. the view from abroad).

\subsubsection{Doing Business 2015: Going Beyond Efficiency}

It is the 12th in a series of annual reports published by the WB measuring the regulations that enhance business activity and those that constrain it. DB measures business regulations that affect domestic small and medium - size firms in 11 areas across 189 economies. Ten of these areas - starting a business, dealing with construction permits, getting electricity, registering property, getting credit, protecting minority investors, paying taxes, trading across borders, enforcing contracts and resolving insolvency -are included in the distance to frontier score and ease of doing the business ranking. Although DB does not capture other aspects of the business environment, such as security, market size, macroeconomic stability and the prevalence of bribery and corruption, business regulations such as those measured by DB are essential for the new business creation and the performance of small firms. Doing Business also measures labor market regulation, which is not included in the 2 measures. Moreover, every year DB recognizes the 10 economies that improved the most in the ease of DB in the previous year and introduced policy changes in 3 or more areas.According to results, Singapore topped the global ranking on the ease of DB for the ninth consecutive year, this time, followed by Hong - Kong, New Zealand. Slovakia was ranked 37th. Table 4 presents the position of the SR according to the key indicators, so the strengths and weaknesses of our business environment are visible.

As we can see from Table 4, WB registered 2 reforms making it easier to do business in Slovakia. Within the indicator Starting a Business the Slovak Republic made starting a business easier by reducing the time needed to register with the district court and eliminating the need (and therefore the fee) for the verification of signatures by a notary public. Within the indicator, Getting Credit the Slovak Republic improved its credit information system by implementing a new law on the protection of personal data. 
Table 4: Position of the SR within DB indicators

\begin{tabular}{|c|c|c|c|}
\hline Topics & $\begin{array}{l}\text { DB } 2015 \\
\text { Rank }\end{array}$ & 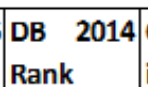 & $\begin{array}{l}\text { Change } \\
\text { in Rank }\end{array}$ \\
\hline $\begin{array}{l}\text { Starting } \\
\text { Business }\end{array}$ & 77 & 83 & 6 \\
\hline $\begin{array}{l}\text { Dealing with } \\
\text { Construction } \\
\text { Permits }\end{array}$ & 110 & 108 & -2 \\
\hline $\begin{array}{l}\text { Getting } \\
\text { Electricity }\end{array}$ & 100 & 96 & -4 \\
\hline $\begin{array}{l}\text { Registering } \\
\text { Property }\end{array}$ & 11 & 10 & -1 \\
\hline Getting Credit & 36 & 30 & -6 \\
\hline $\begin{array}{l}\text { Protecting } \\
\text { Minority } \\
\text { Investors } \\
\end{array}$ & 100 & 97 & -3 \\
\hline Paying Taxes & 100 & 91 & -9 \\
\hline $\begin{array}{ll}\text { Trading Across } \\
\text { Borders }\end{array}$ & 71 & 70 & -1 \\
\hline \begin{tabular}{|l|} 
Enforcing \\
Contracts
\end{tabular} & 55 & 57 & 2 \\
\hline $\begin{array}{l}\text { Resolving } \\
\text { Insolvency }\end{array}$ & 31 & 28 & -3 \\
\hline
\end{tabular}

Source: Doing Business 2015

Note: $\checkmark=$ Doing Business reform making it easier to do business. $X=$ Change making it more difficult to do business.

\subsubsection{Index of Economic Freedom}

For over 20 years The Heritage Foundation, in partnership with The Wall Street Journal has tracked the march of economic freedom around the world with the influential Index of Economic Freedom. Launched in 1995, the Index evaluates countries in four broad policy areas that affect economic freedom: the rule of law; limited government; regulatory efficiency; and open markets. There are 10 specific categories: property rights, freedom from corruption, fiscal freedom, government spending, business freedom, labor freedom, monetary freedom, trade freedom, investment freedom, and financial freedom. Scores in these categories are averaged to create an overall rating.

Based on an average score, each of 178 countries graded in the 2015 Index is classified as "free" (i.e., combined scores of 80 or higher); "mostly free" (70-79.9); "moderately free" (60-69.9); "mostly unfree" (50-59.9); or "repressed" (under 50). Generally speaking, the world economy is "moderately free," with a slight rise in economic liberty leading to a third annual global increase.

According to editors of the report (Heritage Foundation, 2015), "The fundamental relationship between economic freedom and prosperity is readily apparent worldwide," and "No matter the region, per capita income levels, are consistently higher in countries that are economically freer." Hong Kong and Singapore finished first and second in the rankings for the 21 st consecutive year.

Slovakia's economic freedom score is 67.2, making its economy the 50th freest in the 2015 Index. Its score has increased by 0.8 points from last year, with improvements in freedom from corruption, business freedom, and labor freedom outweighing declines in monetary freedom and the management of government spending. Slovakia is ranked 22nd out of 43 countries in the Europe region, and its overall score is higher than the world average (60.4).

Slovakia's basic economic environment still needs improvement. The rule of law is weak, allowing corruption to 
flourish, and there is a lack of transparency in the government and state-owned sector. Despite some progress, business regulations remain inefficient, and labor market rigidity has prolonged the downside of business cycles. The financial crisis and the weak regional environment have undermined public finances. The government's long-term commitment to economic freedom must be renewed to boost prosperity and competition.

\section{Conclusion}

We can come across with different approaches to classification of the business environment in domestic and foreign literature. In this paper, we follow its division into three levels: international, national, local. We present those parts of the social surroundings, which have the most significant influence on the financial decisions of a company. Regarding this, we analyze the development of the basic macroeconomic indicators of the Slovak Republic.

As the results of the international rankings of the entrepreneurial environment reveal, our basic economic environment still needs improvement. Despite some progress, we need to undertake measures regarding the business regulations, administrative burden, corruption, access to finance. Ultimately, the creation of an appropriate business environment is a major factor in corporate sector development, esp. for SMEs as their main part.

\section{References}

- Gertler, L. - Sivák, R. (2013). Country based evidence on sensitivity to leverage, economic cycle and capital buffers. Financial management of firms and financial institutions: proceedings: 9th international scientific conference, p. $196-202$.

- Heritage Foundation. (2015). Index of Economic Freedom. www.heritage.org/index

- Jančovičová Bognárová, K. (2012). Prehl’ad vývojových trendov v oblasti merania finančnej výkonnosti podnikov. Theory of management 6 : the selected problems for the development support of management knowledge base: scientific papers . Žilina: EDIS, p. $220-224$.

- Královič, J. - Vlachynský, K. (2011). Finančný manažment. Bratislava: IURA EDITION.

- Ludvík, L. (2005). Regionální aspekty podnikání. Ostrava: VŠP.

- Needle, D. (2004). Business in context: An introduction to business and its environment. London: Thomson Business Press.

- Rabatinová, M. - Kušnírová, J. (2013). Postavenie dividend v daňovo-odvodovom systéme Slovenskej republiky - história a súčasnost'. Nová Ekonomika. Bratislava: NHF EU, p. 48 - 57

- Š́krovánková, L. - Škrovánková, P., 2012. Stochastické modely v životnom poistení. Slovenská štatistika a demografia, 22(1), p. 3 - 17.

- Válek J. - Neupauerová, Z. (2009). Historický vývoj daní ako hlavný zdroj financovania verejných potrieb na územi Slovenska. Financie a riziko, p. $92-103$.

- World Bank. (2015). Doing Business. www.doingbusiness.org 